\title{
Staying well in old age: Predicting older adults' wellness
}

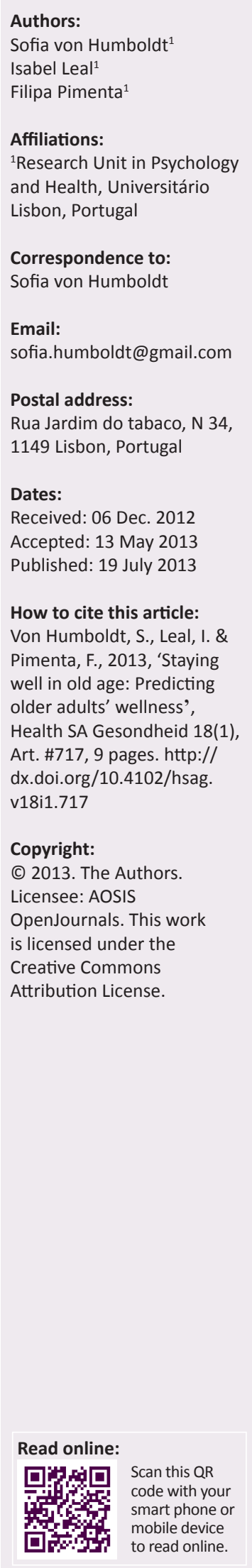

Authors:

Sofia von Humboldt

Isabel Leal ${ }^{1}$

Filipa Pimenta

Affiliations:

and Health, Universitário

Correspondence to:

Sofia von Humbold

\section{Email:}

Postal address:

Rua Jardim do tabaco, N 34

\section{Dates:}

Accepted:

How to cite this article:

Von Humboldt, S., Leal, I. \& well in old age: Predicting older adults' wellness', Health SA Gesondheid 18(1) Art. \#717, 9 pages. http:// dx.doi.org/10.4102/hsag. v18i1.717

Copyright:

Licensee: AOSIS

OpenJournals. This work

is licensed under the

Creative Commons
In an ageing world, the potential for ageing well in older people is still relatively unexplored. Literature has suggested that a sense of coherence (SOC) is an important factor with regard to retaining a good quality of life in old age. To explore whether satisfaction with life (SWL), as well as sociodemographic, health- and lifestyle-related variables, are predictors of SOC in a community-dwelling sample of older adults and to assess significant differences in SOC amongst the four nationalities studied. Cross-national research encompassing a community-dwelling sample of 454 older adults aged 75 years and above was undertaken. Sense of coherence was assessed using the Orientation to Life Questionnaire and Satisfaction with Life (SWL) was measured using the Satisfaction with Life Scale. Structural equation modelling was used to investigate a structural model of the self-reported SOC, comprising sociodemographic variables (age, gender, marital status, professional status, educational level, family's annual income and standard of living arrangements), as well as SWL, lifestyle and health-related (physical activity and recent disease) characteristics. Significant predictors were physical activity $(\beta=0.804 ; p<0.001)$, recent disease $(\beta=0.501 ; p<0.001)$ and SWL $(\beta=0.07$; $p=0.004)$. These variables accounted for approximately $57.5 \%$ of the variability of SOC. Moreover, differences with regard to SOC were also found amongst the four nationality groups $\left(F_{(3)}=5.204 ; p=0.002\right)$. Physical activity is the strongest predictor of self-reported SOC. Other predictors are the absence of a recent disease and SWL. The four nationalities presented significant differences with regard to SOC. This study highlighted the need for understanding the potential factors (in particular physical activity and further health-related characteristics) that impact on older adults' SOC.

In 'n wêreld wat aan die verouder is, is die potensiaal van bejaardes om goed te verouder steeds relatief onbekend. ' $n$ Toenemende literatuurbasis stel voor dat koherensiesin belangrik is om 'n goeie lewensgehalte vir bejaardes te verseker. Om te verken of lewenstevredenheid, sosio-demografiese, gesondheids- en lewenstylverwante veranderlikes voorspellers is van die koherensiesin in 'n steekproef van bejaardes wat nie in tehuise woon nie, asook om die beduidende verskille tussen die vier nasionaliteite met betrekking tot die koherensiesin te evalueer. Kruis-nasionale navorsing bestaande uit'n steekproef van 454 volwassenes, 75 jaar of ouer, wat nie in tehuise woon nie. Koherensiesin is met behulp van die lewensoriëntasievraelys beoordeel en lewenstevredenheid is met behulp van die lewenstevredenheidskaal gemeet. Strukturele vergelykingsmodellering is gebruik om 'n strukturele model van die selfgerapporteerde koherensiesin te ondersoek. Die model bestaan uit sosio-demografiese veranderlikes (ouderdom, geslag, huwelikstatus, professionele status, opvoedkundige vlak, gesin se jaarlikse inkomste en lewensomstandighede), asook lewenstevredenheid, lewenstyl- en gesondheidsverwante (fisiese aktiwiteitsvlak en onlangse siekte) eienskappe. Beduidende voorspellers is fisiese aktiwiteitsvlak $(\beta=.804 ; p<0.001)$, onlangse siekte $(\beta=.501$; $p<0.001)$ en lewenstevredenheid $(\beta=.07 ; p=0.004)$. Die veranderlikes verklaar onderskeidelik $57.5 \%$ van die wisselvalligheid van die koherensiesin. Verder is daar ook verskille tussen die vier nasionaliteite met betrekking tot koherensiesin $\left(F_{(3)}=5.204 ; p=0.002\right)$ gevind. Fisiese aktiwiteitsvlak is die sterkste voorspeller van self-gerapporteerde koherensiesin. Ander voorspellers is lewenstevredenheid en die afwesigheid van onlangse siekte. Die vier nasionaliteite het duidelike verskille ten opsigte van koherensiesin getoon. Hierdie studie beklemtoon die noodsaaklikheid om die potensiële faktore - veral fisiese aktiwiteitsvlak en verdere gesondheidsverwante eienskappe - wat bejaardes se koherensiesin beïnvloed, te verstaan.

\section{Introduction}

\section{Problem statement}

The world's population is ageing, with the mean age in countries around the world rising rapidly. In more-developed regions, over a fifth of the population is currently aged 60 years or over and by 
2050, nearly a third of the population in developed countries is projected to be in that age group. In less-developed regions, older persons account for just $8 \%$ of the population but by 2050 they are expected to account for approximately $20 \%$ of the population, implying that, by mid-century, the developing world is likely to reach the same stage in the process of population ageing that the developed world is already at (United Nations 2009). The population of older persons worldwide is growing at a rate of $2.6 \%$ per year considerably faster than the population as a whole, which is increasing at $1.2 \%$ annually (United Nations 2009). Indeed, the issues surrounding population ageing are profound, having major consequences and implications for all facets of human life.

Issues related to population ageing and older persons in general have secured a prominent role in the literature surrounding health and social policy. For example, the International Conference on Population and Development, held in 1994, recognised that the economic and social impact of population ageing is both an opportunity and a challenge to all societies (United Nations 2009).

The need for all societies to address the significant consequences of population ageing, namely the challenge of maintaining health and well-being in old age, has been reiterated worldwide (Fernández-Ballesteros 2007:15; United Nations 2009). Considering that sense of coherence (SOC) was developed in an approach that focused on factors that support human health and well-being, the study of SOC is pertinent amongst older populations.

To fully understand SOC and its development, knowledge about factors contributing its development is needed. Hence, the analysis of the impact of satisfaction with life (SWL), sociodemographic, lifestyle and health-related factors on SOC, in the multi-dimensional and multi-cultural context of ageing well, is essential.

\section{Literature review}

Currently, 21\% of the population in the more-developed regions around the world is aged 60 years or over, whereas only about $8 \%$ of the population in the less-developed regions is in that age group. Europe currently has the highest proportion of older persons and it is projected that this status quo will remain until 2050. Nearly 35\% of the population of Europe is projected to be 60 years or over in 2050 - an increase from 22\% in 2009 (United Nations 2009). Furthermore, previous literature has already highlighted the fact that cultural, national and ethnic differences may influence the process of ageing (Barak 2009; Löckenhoff et al. 2009; Torres 2003). The proportion of people aged 65 or over in Africa is projected to rise from 3\% in 2009 to $7 \%$ in 2050 (United Nations 2009). Although data collection efforts regarding the status of older Africans have increased in recent years (Charlton 1998; Ferreira et al. 1992), there is still a paucity thereof. The size of the elderly population in subSaharan Africa is expected to jump by $50 \%$ between 2000 and
2015 - from 19.3 million to 28.9 million people (Kinsella \& Velkoff 2001). It is interesting to note that South Africa, in particular, has a higher proportion of women at older ages than many European countries (United Nations 2009).

Increasing longevity may result in growing challenges, such as longer pensions and a greater need for health care and old-age support. It also highlights the need to make the best of the opportunities that an ageing population brings (e.g. longer employment opportunities, family composition and migration trends) (Fernández-Ballesteros 2007; United Nations 2009).

Public health research has shown that social and personality factors are amongst the key determinants of health and well-being (Volanen et al. 2004:322). In this context, SOC is a global orientation that expresses the extent to which one has a pervasive, enduring, dynamic feeling of confidence that (a) the stimuli deriving from one's internal and external environments in the course of one's life are structured, predictable, and explicable; (b) suitable resources are available to meet the demands posed by these stimuli; and (c) these demands are challenges, worthy of investment and engagement (Antonovsky 1987:19). Moreover, Antonovsky $(1979,1987)$ developed his salutogenic model of health, an approach focusing on factors that support human health and well-being, rather than focusing on factors that cause disease. SOC seems to be a health-promoting resource, which strengthens resilience and develops a positive, subjective state of health (Amirkhan \& Greaves, 2003; Eriksson \& Lindström 2006). Growing research comprises several studies on the topic of SOC and older adults (Dragaset et al. 2008; Sagy \& Antonovsky 1990; Steiner et al. 1996; Surtees et al. 2003).

Considering the relevance of living well in old age and the specific challenges for health and well-being into old age, there is a wealth of studies with regard to SOC as a predictor of health both in community and clinical settings (Antonovsky \& Sagy 1985; Henje Blom et al. 2010; Kalimo et al. 2003; Kivimäki et al. 2000; Larsson \& Kallenberg 1996; Sairenchi et al. 2011; Suominen et al. 2001) and psychological variables such as well-being, SWL and quality of life (Kalimo \& Vuori 1990; Petrie \& Brook 1992; Söderberg, Lundman \& Nordberg 1997). That being said, the background predictors of SOC have been much less examined (Volanen et al. 2004:322, 2006:515); in fact, only a few earlier studies have focused on the factors promoting SOC. In spite of its psychological nature, it has been shown that sociodemographic and healthrelated variables may have an impact on SOC (Volanen et al. 2004, 2006), especially social class, age and work conditions (Larsson \& Kallenberg 1996; Lundberg 1996; Lundberg \& Nyström Peck 1994). Moreover, in a study by Larsson and Kallenberg (1996), youth, occupation, income and household size were all related to strong SOC. In addition, the level of education, occupational status and income in adulthood also promoted a strong SOC (Leppänen 1999).

Previous studies also have found a stronger SOC amongst men than women (Anson et al. 1993; Antonovsky \& Sagy 
1985; Larsson \& Kallenberg 1996; Suominen et al. 1999). Additionally, social support had a positive effect on SOC (Larsson \& Kallenberg 1996; Wolff \& Ratner 1999). In brief, previous studies suggest that both sociodemographic and health factors contribute to SOC. However, partiallycontrasting findings regarding, for example, the effect of age, education and living conditions on SOC, have been obtained and present no consensus in literature given that they might predict either an increase or a significant decrease in SOC (Larsson \& Kallenberg 1996; Leppänen 1999; Lundberg 1996, 1997; Lundberg \& Nyström Peck 1994; Suominen 1993; Suominen et al. 1999; Volanen et al. 2004; Wolff \& Ratner 1999). Moreover, the authors of the present study found no previous studies regarding the effect of SWL and lifestyle factors on SOC. Furthermore, to the best knowledge of the authors there are no previous studies that explore the simultaneous impact of sociodemographic, lifestyle and health-related factors on the SOC of older adults. This research is, therefore, designed to develop a comprehensive picture of the role of SWL and sociodemographic, lifestyle and health-related factors in predicting SOC amongst the elderly.

\section{Research questions}

This study had two main research questions: (1) Are the following factors: SWL, sociodemographic, health- and lifestyle-related variables, predictors of SOC in a communitydwelling sample of older European adults?; and (2) Do the four nationalities present significant differences with regard to SOC?

\section{Rationale for the study}

As pointed out earlier, most previous studies have centered on SOC as a predictor factor for health and other psychological variables. In addition, a few earlier studies have focused on the factors predicting SOC with partially-contrasting findings. Moreover, our review of the literature failed to uncover the predictors for SOC amongst older populations. The rationale of the study is, therefore, to provide fresh data on the simultaneous impact of SWL, sociodemographic, lifestyle and health-related factors on the SOC of older adults. Literature has suggested that SOC is important for good quality of life in old age (Surtees et al. 2003). This study aims to provide a model to predict SOC in a sample of Angolan, Brazilian, English and Portuguese older adults and to assess cross-national differences concerning SOC.

\section{Research method and design Study design}

A quantitative approach was followed with a descriptive and cross-sectional study design (Bowling \& Ebrahim 2005:120; Burns \& Grove 2001:61; Mouton 1996:103), targeted at community-dwelling older adults residing in Portugal.

A quantitative approach and a descriptive design method refer to the structured statistical analysis of the profile (demographic data) of the participants included in the study (Babbie \& Mouton 2001:49; Polit \& Hungler 1995:15).
Descriptive methods are not always highly structured. According to Bowling and Ebrahim (2005:120), a crosssectional study can be described as a measurement of the frequency of a specific attribute, in a defined sample population at a certain point in time. The cross-sectional design of our study was appropriate for obtaining a snapshot of predictors of SOC amongst community-dwelling older adults, without manipulating the study environment. This design also allowed us to compare different variables (e.g. sociodemographic) and population groups at a single point in time - in this case, the elderly from four different nationalities. The information obtained is specific to this study and cannot be generalised because of the limitations posed by convenience sampling methods.

\section{Study population and sampling}

A community sample of 454 community-dwelling older adults from four different nationalities (Angolan, Brazilian, English and Portuguese) who had resided in Portugal for more than 10 years, filled in the self-report measures designed to assess their sociodemographic, lifestyle- and health-related variables, as well as their SOC. Participants were aged 75 years and over, with an average age of 84 (standard deviation $=6.71$ years). The sample comprised 282 females (62.1\%), 239 married participants (52.6\%) and 240 living in urban areas (52.9\%). The recruitment of participants was performed through lifelong learning centres' message boards, local and art community centres' list-serves in the Lisbon metropolitan area and in the Algarve region of Portugal. All these participants had a minimum 10-year longterm lawful residence, which excluded possible influences on SOC.

A number of participants were living with their children. This occurred amongst participants from all four nationalities studied, especially when they were not living in their country of origin.

A convenience sampling method was used to select the participants (Polit \& Beck 2008:341). Participants who were not residents of any European country and who had been diagnosed with concurrent psychiatric disorders, according to DSM-IV criteria (American Psychiatric Association 1994), were excluded.

In this context, participants with previous psychiatric disease, including major illness, anxiety, depression, or with known substance abuse disorders, were excluded. This was done to remove possible confounding variables that may have had an impact on SOC. Participants were also excluded if they had difficulty in completing the Mini-Mental State Examination (MMSE) (Folstein, Folstein \& McHugh 1975), which was administered to all of the participants (results summarised in Table 1).

\section{Materials}

The measurement materials, including the Orientation to Life Questionnaire (OLQ) and the Satisfaction with Life 
TABLE 1: Characterisation of participants in relation to sociodemographic, health and lifestyle variables.

\begin{tabular}{|c|c|c|c|c|c|c|c|c|c|c|}
\hline \multirow{2}{*}{$\begin{array}{l}\text { Sociodemographic, health and } \\
\text { lifestyle variables }\end{array}$} & \multicolumn{2}{|c|}{ Angolan } & \multicolumn{2}{|c|}{ Brazilian } & \multicolumn{2}{|c|}{ English } & \multicolumn{2}{|c|}{ Portuguese } & \multicolumn{2}{|c|}{ Total } \\
\hline & $n$ & $\%$ & $n$ & $\%$ & $n$ & $\%$ & $n$ & $\%$ & $n$ & $\%$ \\
\hline$N$ & 101 & 22.2 & 111 & 24.5 & 118 & 26.0 & 124 & 27.3 & 454 & 100.0 \\
\hline Age (Mean) & 83.2 & - & 84.2 & - & 83.8 & - & 84.7 & - & 84.0 & - \\
\hline Age (Standard Deviation) & (6.384) & - & $(6.620)$ & - & $(6.620)$ & - & $(7.200)$ & - & $(6.706)$ & - \\
\hline \multicolumn{11}{|l|}{ Gender } \\
\hline Male & 47 & 46.5 & 37 & 33.3 & 38 & 32.2 & 50 & 40.3 & 172 & 37.9 \\
\hline Female & 54 & 53.5 & 74 & 66.7 & 80 & 67.8 & 74 & 59.7 & 282 & 62.1 \\
\hline \multicolumn{11}{|l|}{ Education } \\
\hline High school & 39 & 38.6 & 41 & 36.9 & 46 & 39.0 & 45 & 36.3 & 171 & 37.7 \\
\hline High school or higher & 62 & 61.4 & 70 & 63.1 & 72 & 61.0 & 79 & 63.7 & 283 & 62.3 \\
\hline \multicolumn{11}{|l|}{ Marital Status } \\
\hline Married or in a relationship & 53 & 52.5 & 86 & 77.5 & 42 & 35.6 & 58 & 46.8 & 239 & 52.6 \\
\hline Not married nor in a relationship & 48 & 47.5 & 25 & 22.5 & 76 & 64.4 & 66 & 53.2 & 215 & 47.4 \\
\hline \multicolumn{11}{|l|}{ Professional Status } \\
\hline Inactive & 42 & 41.6 & 27 & 24.3 & 82 & 69.5 & 62 & 50.0 & 213 & 46.9 \\
\hline \multicolumn{11}{|l|}{ Family Annual Income } \\
\hline$\leq 10000 €$ & 53 & 52.5 & 68 & 61.3 & 49 & 41.5 & 64 & 51.6 & 234 & 51.5 \\
\hline$\geq 10001 €$ & 48 & 47.5 & 43 & 38.7 & 69 & 58.5 & 60 & 48.4 & 220 & 48.5 \\
\hline \multicolumn{11}{|l|}{ Living Conditions } \\
\hline Urban & 59 & 58.4 & 67 & 60.4 & 55 & 46.6 & 59 & 47.6 & 240 & 52.9 \\
\hline Rural & 42 & 41.6 & 44 & 39.6 & 63 & 53.4 & 65 & 52.4 & 214 & 47.1 \\
\hline \multicolumn{11}{|l|}{ Physical Activity } \\
\hline Yes & 48 & 47.5 & 45 & 40.5 & 48 & 40.7 & 60 & 48.4 & 201 & 44.3 \\
\hline No & 53 & 52.5 & 66 & 59.5 & 70 & 59.3 & 64 & 51.6 & 253 & 55.7 \\
\hline \multicolumn{11}{|l|}{ Recent Disease } \\
\hline Yes & 41 & 40.6 & 34 & 30.6 & 42 & 35.6 & 57 & 46.0 & 174 & 38.3 \\
\hline No & 60 & 59.4 & 77 & 69.4 & 76 & 64.4 & 67 & 54.0 & 280 & 61.7 \\
\hline
\end{tabular}

Source: Authors' own construction

Scale (SWLS), as well as demographics, were used for the comprehensive characterisation of the main outcomes of this study.

The participants' SOC was assessed by means of the Orientation to Life Questionnaire, which covered the three main subcomponents of SOC: comprehensibility, manageability and meaningfulness (Antonovsky 1987, 1993). The OLQ comprises 29 items which ask individuals to rate the extent to which they agree (on a seven-point Likert-type scale) to items such as: 'How often do you have the feeling that there's little meaning in the things you do in your daily life?' and 'How often do you have feelings that you're not sure you can keep under control?'. Negative items were reverse-scored, meaning that higher scores on this scale indicate greater levels of SOC. In previous studies, the OLQ presented good psychometric properties, including the measure of internal consistency which ranged from 0.82 to 0.95 (Antonovsky 1993; Eriksson \& Lindström 2006).

To evaluate the participants' SWL - the cognitive appraisal of the participants' overall subjective well-being - the validated version of the SWLS was applied (Diener et al. 1985). The SWLS is a five-item, self-reporting measure presented on a seven-point Likert-type scale that ranges from 'strongly disagree' to 'strongly agree'. Items included such statements as 'In most ways my life is close to my ideal' or 'I am satisfied with my life'. The five-item instrument presented good psychometric properties, including an alpha coefficient equaling 0.87 (Diener et al. 1985).
Sociodemographic characteristics (age, gender, marital status, professional status, educational level, living conditions and family's annual income), as well as lifestyle and healthrelated characteristics (recent disease and physical exercise) were also assessed. The sociodemographic, health- and lifestyle-related variables were quantified and integrated into the structural equation model in order to assess their possible influence on the participants' SOC.

\section{Procedure}

The participants were provided with a brief description of the study over the phone or in person and were invited to participate in the study. It was emphasised that participation in this research was voluntary and that participants could terminate their collaboration at any time, without any negative consequences.

Once informed consent had been received, the participants went through a cognitive screening assessment to determine eligibility, using the MMSE (Folstein et al. 1975). After the initial screening, the participants completed their questionnaires under the supervision of a postgraduate psychology student. They had an opportunity to seek clarification with regard to how the questionnaires should be completed, as well as with regard to any questions they found difficult to understand. A code number was given to each participant and the scores were indicated next to this number.

The questionnaires were filled in by 458 older adults. Four were subsequently excluded for not providing complete 
information regarding their sociodemographic, healthand lifestyle-related characteristics. Some of the final 454 participants asked to be informed of the results at the end the study.

\section{Statistical analysis}

The internal consistency of the OLQ and SWLS were investigated by calculating the Cronbach alpha coefficients for the three subscales of the OLQ (comprehensibility = 0.956; manageability $=0.921$; significance $=0.901$ ), as well as for the total SOC score (0.932) and for the total score of the SWLS (0.887). All measures indicated satisfactory levels of internal consistency, in that the corresponding alpha coefficients exceeded 0.7 (Foster \& Parker 1995). Therefore, the data gained via these two questionnaires can be used with confidence for additional statistical analysis.

To start, the data were analysed to check for outliers and distribution forms. No missing value imputation was made. Next, the data were analysed by means of descriptive statistics for the sociodemographic, lifestyle and healthrelated variables, SWL and SOC. Multicollinearity between the independent variables was explored using the variance inflation factor provided by the Statistical Package for Social Sciences (SPSS) programme (version 19.0; SPSS Inc., Chicago, IL). All variables presented a value below ' 5 ', indicating the absence of collinearity (Maroco 2010; Weisberg 1985). To test the structural model for SOC, a structural equation model was built relating the dependent variable (SOC) with ten independent variables (age, gender, marital status, professional status, family's annual income, educational level, living conditions, absence of a recent disease, physical activity and SWL). The model was evaluated using SPSS and Analysis of Moment Structures (AMOS) software for Windows (version 19.0; SPSS Inc., Chicago, IL). The quality of the fit of the structural model was given by chi-square statistics $\left(X^{2} / \mathrm{df}\right)$, comparative fit index $(\mathrm{CFI})$, goodness of fit index (GFI) and root mean square error of approximation (RMSEA). The reference values were used the reference values currently practised in structural equation modelling (Byrne 2001; Maroco 2010).

A two-step approach was employed in order to evaluate the structural model. Firstly, the measurement model was evaluated to demonstrate an acceptable fit. Thereafter, the structural model, encompassing the dependent and the ten independent variables, was adjusted and the significance of the structural trajectories was evaluated.

In order to determine whether nationality groups diverged significantly concerning their SOC scores, group differences were evaluated by means of the one-way analysis of variance
(ANOVA), followed by a post-hoc Tukey's test. These were run and analysed using the SPSS software.

\section{Results}

Confirmatory factor analysis of the Orientation to Life questionnaire $\left(X^{2} / \mathrm{df}=2.069 ; \mathrm{CFI}=0.969 ; \mathrm{GFI}=0.903\right.$; RMSEA $=0.049 ; C I$ [confidence interval] $=90 \%$ [0.044; 0.053]; $p=0.538)$ and of the SWLS $\left(X^{2} / \mathrm{df}=1.847 ; \mathrm{CFI}=0.998\right.$; $\mathrm{GFI}=0.992 ; R M S E A=0.043 ; \mathrm{CI}=90 \%[0.000 ; 0.086] ; p=0.538)$ presented a good fit in our study.

The measurement model $\left(X^{2} / \mathrm{df}=2.121 ; \mathrm{CFI}=0.962\right.$; $\mathrm{GFI}=0.884 ; \mathrm{RMSEA}=0.050 ; \mathrm{CI}=90 \%[0.046 ; 0.054]$; $p=0.535)$, as well as the structural model $\left(X^{2} / \mathrm{df}=1.816\right.$; $\mathrm{CFI}=0.959 ; \mathrm{GFI}=0.877$; $\mathrm{RMSEA}=0.042 ; \mathrm{CI}=90 \%[0.039$; 0.046]; $p=1.000$ ), showed a good fit. Significant predictors are highlighted in Figure 1.

As shown, the structural model accounts for $57.5 \%$ of the variability of the participants' SOC. Significant predictors are physical activity $(\beta=0.804 ; p<0.001)$, recent disease $(\beta=0.501 ; p<0.001)$ and SWL $(\beta=0.072 ; p=0.004)$.

The Angolan participants, on the whole, scored higher for SOC $(\mathrm{M}=4.77$; $\mathrm{SD}=1.001)$, whilst the English participants scored the lowest $(\mathrm{M}=4.39$; $\mathrm{SD}=0.943)$. This led to the Angolans having a significant but not considerably higher mean average of SOC than the English and Brazilian participants. Furthermore, the ANOVA results indicated that in this community-dwelling sample, the SOC score presented significant but not substantial differences between at least two nationalities $\left(F_{(3)}=5.204 ; p<0.01\right)$ (see Table 2 ), namely between the Angolan and Brazilian or English participants and between the English and Portuguese participants (see Table 3). Post-hoc comparisons of means (Tukey's honestly significant difference) indicated that the Angolan

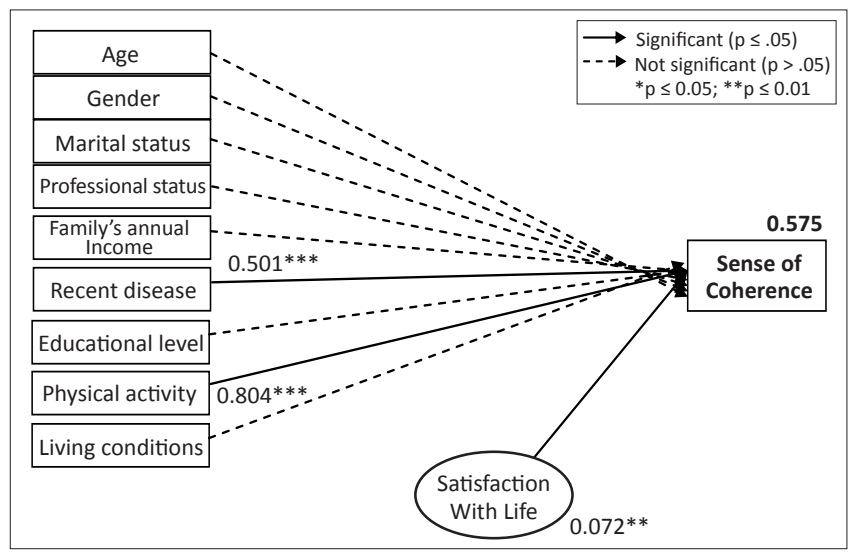

Source: Authors' own construction

FIGURE 1: Structural model for Sense of Coherence and its relationship with Satisfaction with Life, sociodemographics, lifestyle- and health-related variables.

TABLE 2: Cross-national differences in the Sense of Coherence.

\begin{tabular}{lcccc}
\hline National differences & Angolan M(SD) & Brazilian M(SD) & English M(SD) & Portuguese M(SD) \\
\hline SOC Total Score & $4.77(1.001)$ & $4.41(0.883)$ & $4.39(0.943)$ & One Way ANOVAF (df)p* \\
\hline
\end{tabular}


TABLE 3: Tukey's Honestly Significant Difference multiple comparison test.

\begin{tabular}{lllcc}
\hline Nationality comparison & Mean Difference & Std. Error & \multicolumn{2}{c}{$\begin{array}{c}95 \% \text { Confidence } \\
\text { Interval }\end{array}$} \\
\cline { 4 - 6 } & & & $\begin{array}{c}\text { Lower } \\
\text { Bound }\end{array}$ & $\begin{array}{c}\text { Upper } \\
\text { Bound }\end{array}$ \\
\hline Angolan vs. Brazilian & $0.359^{*}$ & 0.129 & 0.03 & 0.69 \\
Angolan vs. English & $0.386^{*}$ & 0.127 & 0.06 & 0.71 \\
Angolan vs. Portuguese & 0.050 & 0.126 & -0.27 & 0.37 \\
Brazilian vs. English & 0.027 & 0.124 & -0.29 & 0.35 \\
Brazilian vs. Portuguese & -0.309 & 0.123 & -0.63 & 0.01 \\
English vs. Portuguese & $-0.336 *$ & 0.121 & -0.65 & -0.03 \\
\hline
\end{tabular}

Source: Authors' own construction

$*, p \leq 0.05$

participants had a significantly higher SOC score than the Brazilians ( $\mathrm{MD}=0.359 ; p=0.028)$ and the English $(\mathrm{MD}=$ $0.386 ; p=0.013$ ). Additionally, the Portuguese participants had a significantly higher SOC score than the English (MD = 0.336; $p=0.028$ ) (see Table 3). No significant differences were seen when comparing the Portuguese participants' score against the Angolans' and Brazilians' scores, as also seen in Table 3.

\section{Ethical considerations}

This study constitutes part of a multi-phase project entitled, 'Older adults' adjustment to ageing and subjective well-being' for which ethical approval was given by the Research Unit in Psychology and Health at ISPA - Instituto Universitário. This study was conducted according to the guidelines laid down by the Declaration of Helsinki and the American Psychological Association's standards on ethical treatment of participants.

The ethical principles of respect for autonomy, nonmaleficence, beneficence and justice were thus adhered to throughout the research process (Dhai \& McQuoidMason 2011:43-44). Informed consent was received from all participants and the study protocol was approved by the Research Unit in Psychology and Health.

The participants' private information was not shared without the individuals' knowledge or against their will. Also, participants were informed that participation in this research was voluntary and that they could terminate their collaboration at any time, without any consequences. No private information was requested. With this in mind, the information about income was asked considering a cut-off point of 10000 Euros (i.e. not asking for participants' specific income), so there was no invasion of privacy. No invasive procedures were administered, nor were anthropometric, biochemical or blood measurements collected. The selection process of participants was done fairly as each participant fitting the criteria had an equal chance of being selected.

Only questionnaires, and no other content, were completed by the respondents, and no risk or hazards were involved. Questionnaires were completed in the participants' homes. The participants, therefore, did not incur any financial expense (Burns \& Grove 2001:196; DENOSA 1998:23). Benefits for the participants included being given an opportunity to indicate their perspectives on SOC and SWL in a positive, supportive environment, in order to contribute to the scientific knowledge about what contributes to ageing well.

\section{Discussion}

Sociodemographic variables (such as age, gender, marital status, educational level, professional status, living conditions and family's annual income) were not significant predictors of SOC. These results go against what has been seen in other studies (Anson et al. 1993; Antonovsky \& Sagy 1985; Larsson \& Kallenberg 1996; Leppänen 1999; Lundberg 1996, 1997; Lundberg \& Nyström Peck 1994; Suominen 1993; Suominen et al. 1999; Volanen et al. 2004; Wolff \& Ratner 1999). The absence of relationship between gender and educational level has also been reported (Larsson \& Kallenberg 1996; Lundberg \& Nyström Peck 1994). It is possible that alternative sociodemographic influences on older adults' SOC, such as contextual social support and civic participation, may also reflect the shifting demographic reality and lifestyles amongst the community-dwelling elderly.

Unexpectedly, marital status was unrelated to SOC amongst our participants. Conversely, Volanen and her colleagues (2004) found that a poor relationship with a partner was a major threat to SOC. Moreover, the bearing of the quality of family relationships and family life on SOC has been neglected in the SOC literature (Volanen et al. 2004). The family's income and educational level were also unrelated with SOC, which again did not corroborate previous literature. SOC is primarily an attitude held by people who are well-educated and occupy higher socioeconomic positions (Geyer 1997). That being said, it seems necessary that SOC needs to be regarded from a wider viewpoint, including life spheres other than just people's socioeconomic and educational characteristics.

Although previous research indicated the positive effects of an active professional status on older adults' SOC, our outcomes did not suggest this potential relation. Having poor working conditions and a passive job might weaken one's SOC (Larsson \& Kallenberg 1996; Lundberg 1996; Volanen et al. 2004). Furthermore, as suggested in previous studies, success in fulfilling challenges may yield more 'positive subjective age' (Kleinspehn-Ammerlahn, Kotter-Grühn \& Smith 2008:384; Ward 2010) and productive activities should contribute to the well-being of older adults (Wahrendorf \& Siegrist 2010:67).

Very few studies approached the health factors that affect SOC. There are, however, many studies about the predictive nature of SOC toward health (Eriksson \& Lindström 2006; Larsson \& Kallenberg 1996; Lundberg 1996; Söderberg, Lundman \& Nordberg 1997; Volanen et al. 2004, 2006). Our findings corroborated these studies, as the absence of recent disease and the practice of physical activity were positively and significantly related to SOC amongst our participants. In fact, as also stated by Antonovsky (1987), a stronger 
SOC is associated with better perceived health in general, a relationship that has been manifested in previous studies, regardless of age, sex, ethnicity, nationality and study design (Antonovsky 1993; Eriksson \& Lindström 2006). Previous studies have found SOC to be associated with health and it may also be a potential reason or mediating process for psychosocial and socioeconomic inequalities in health (Anson et al. 1993; Suominen et al. 1999; Vahtera \& Pentti 1995). Additionally, a healthy lifestyle was frequently indicated as contributing to ageing well (Bowling 2007; Smith et al. 2002).

To the best of our knowledge, the absence of recent disease and the presence of physical activity have not been shown to be predictors of SOC in other research. However, in this study, these two variables are, in fact, very strong positive predictors of SOC. Specifically, older adults that reported physical activity showed a higher SOC score than those that did not perform any sort of physical activity. Physical engagement has been found to increase the cognitive function of older adults and to provide an opportunity for social interactions and civic life, as well as to develop a personal sense of meaning (Park et al. 2007; Wilson et al. 2002). It is therefore possible that this factor is associated in part with social support, sense of purpose and self-esteem, which were not controlled for in this research and could possibly promote the increase of SOC.

In this sample, the relationship between SWL and SOC was positive and significant after controlling for all the sociodemographic, health and lifestyle-related characteristics mentioned above. Although SWL had the weakest positive impact on SOC, it can also be hypothesised that SWL was associated with the accomplishment of relevant goals in life, as suggested in previous literature (Nimrod \& Kleiber 2007; Ryff 1989). It seems appropriate to mention that the SWLS measures primarily the cognitive aspects of well-being and our results suggest that this cognitive-focused measuring instrument shows a significant relationship with SOC. The fact that SWL predicted SOC emphasises the importance of a positive cognitive appraisal. Additionally, SWL has been identified, along with physical well-being and health promotion, as being essential for successful ageing (Brown, Bowling \& Flynn 2004). In this context, we hypothesised that SWL and cognitive-based interventions with older adults might enhance their SOC.

Considering the cross-national and cultural diversity of our participants, the highest scores were achieved by Angolan participants, whilst the English produced the lowest mean SOC scores. One possible explanation for these results could be that cultural, national and ethnic differences may influence the process of ageing (Barak 2009; Löckenhoff et al. 2009; Torres 2003). Therefore, as expected given the significant but not substantial culture-related differences amongst the four nationalities studied, our results indicated a diversity of SOC. Moreover, we hypothesised that a specifically African definition of being old, in part due to a recent past of war and poverty (World Health Organization 2003) might have led Angolan participants to a higher appreciation of their sense of purpose, social support and self-esteem, which could promote the increase of SOC.

\section{Limitations and implications of the study}

Our study offers a valuable contribution to the gerontological literature. However, the results need to be interpreted within the context of the following limitations.

Although a diverse sample of participants was recruited, the propensity for this study to be generalised is limited by our use of a convenience sampling method. As stated, the study was confined to European residents. The sample size (namely, 454 participants) was, however, deemed to be adequate for this type of statistical analysis given current practice in structural equation modelling, which is to apply a rule of thumb yardstick of ten subjects per manifest variable (Kline 2005; Maroco 2010). Further research may be improved by using larger sample sizes in order to increase the strength of the investigation (Howell 2004). Furthermore, although significant differences were found between groups, these were not substantial. Further research with larger samples may increase the reliability of these findings, as their clinical relevance has yet to be determined. These findings need to be interpreted for practical use in order to avoid overrating of differences, although the results did seem to show a statistical significance. Given the existence of various cultural and national influences in the European context, the inclusion of race and ethnicity as variables in future research could enhance the understanding of specific factors and the role that those play in predicting SOC in older adults.

Furthermore, the psycho-emotional factors behind SOC, such as meaningful relationships and interpersonal attachment, self-esteem and sense of purpose need to be studied more deeply in future research. Further longitudinal studies are needed in order to confirm the stability of the found predictors.

In spite of the limitations, we think that the findings of this study contribute to a better understanding of SOC in older adults. Firstly, the data came from a varied cross-national sample of the European older population. Secondly, the study examined a broad range of factors, including not only sociodemographic ones, but also health and lifestyle factors.

This study also provides a basis for further research, specifically, in designing and implementing effective intervention programmes for older adults, which include physical activity, prevention of disease and SWL, in order to contribute to a better SOC, as suggested by our outcomes.

\section{Conclusion}

This research was aimed at investigating whether SWL, sociodemographic, health- and lifestyle-related variables were predictors of SOC in a community-dwelling sample of older European adults and to assess significant differences with regard to SOC in the four nationalities studied. 
Overall, the findings suggest that SOC seems to be affected positively by physical activity, the absence of recent disease and SWL.

Physical activity is the strongest positive predictor of SOC. Older adults that reported physical activity showed higher SOC scores as compared with those who did not perform physical activity. The absence of recent disease and SWL are also significant positive predictors of SOC. The structural model explored in this study accounts for $57.5 \%$ of the variability of SOC.

To the best of our knowledge, there are no previous studies exploring the simultaneous impact of sociodemographic, lifestyle- and health-related factors on SOC in older adults and, in particular, including the effects of the cognitive dimension of subjective well-being (SWL) on SOC in these older adults. This research also emphasises the importance of SWL on SOC and contributes with a structural model that integrates SWL and sociodemographic, lifestyle- and healthrelated factors. Our study therefore presents new data with regard to the specific impact of physical activity, absence of recent disease and SWL on SOC in the elderly.

Our findings also emphasise the fact that there are crossnational differences regarding SOC and lend further support to the idea that cultural and ethnical differences may influence this variable. In fact, the potential of older people for ageing well in different cultures is still relatively unexplored, as is the underdeveloped potential of the SOC concept in this population. Considering that ageing is a multi-dimensional concept, sociodemographic, cultural, national and ethnic differences may influence the process of ageing (Barak 2009; Löckenhoff et al. 2009; Torres 2003). With this is mind, this study's outcomes could be useful for health care professionals when dealing with cross-national differences (e.g., physical activity, SWL promotion and disease prevention) amongst older populations. In brief, we assert that the results of this study are an original contribution for a better understanding of what actually predicts SOC in older adults, within the multi-dimensional and cross-national context of age and the ageing process, in combination with an approach focused on health and well-being in older populations.

\section{Acknowledgements}

The authors kindly acknowledge the Portuguese Foundation for Science and Technology (FCT) for funding received which assisted in the realisation of this research [grant number SFRH/BD/44544/2008] and the older adults who volunteered to participate in the study.

\section{Competing interests}

The authors declare that they have no financial or personal relationship(s) which may have inappropriately influenced them in writing this article.

\section{Authors' contributions}

S.v.H. was responsible for the study concept and design, analysis and interpretation of data and elaboration of the manuscript. I.L. and F.P. made conceptual contributions and reviewed the manuscript. All authors read and approved the final manuscript.

\section{References}

Amirkhan, J.H. \& Greaves, H., 2003, 'Sense of coherence and stress: the mechanics of a healthy disposition', Psychology and Health 18(1), 31-62. http://dx.doi. org/10.1080/0887044021000044233

American Psychiatric Association, 1994, Diagnostic and statistical manual of mental health disorders, American Psychiatric Association, Washington, DC.

Anson, O., Paran, E., Neumann, L. \& Chernichovsky, D., 1993, 'Gender differences in health perceptions and their predictors', Social Science \& Medicine 36(4), 419427. http://dx.doi.org/10.1016/0277-9536(93)90404-R

Antonovsky, A., 1979, Health, stress and coping, Jossey-Bass Publishers, San Francisco.

Antonovsky, A., 1987, Unraveling the mystery of health - How people manage stress and stay well, Jossey-Bass Publishers, San Francisco.

Antonovsky, A., 1993, 'The structure and properties of the sense of coherence scale', Social Science and Medicine 36(6), 725-733. http://dx.doi.org/10.1016/02779536(93)90033-Z

Antonovsky, A. \& Sagy, S., 1985, 'The development of a sense of coherence and its impact on responses to stress situations', Journal of Social Psychology 126(2), 213-225.

Babbie, E. \& Mouton, J., 2001, The practice of social research, Oxford University Press, Cape Town.

Barak, B., 2009, 'Age identity: A cross-cultural global approach', International Journal of Behavioral Development 33(1), 2-11. http://dx.doi. org/10.1177/0165025408099485

Bowling, A., 2007, 'Aspirations for older age in the 21st century: What is successful aging?' International Journal of Aging and Human Development 64(3), 263-297. $\mathrm{http}: / / \mathrm{dx}$.doi.org/10.2190/LOK1-87W4-9R01-7127, PMid:17503689

Bowling, A. \& Ebrahim, S., 2005, Handbook of health research methods: Investigating, measurement and analysis, Open University Press, Berkshire.

Brown, J., Bowling, A. \& Flynn, T., 2004, Models of quality of life: a taxonomy, overview and systematic review of the literature, European Forum on Population Ageing Research, Department of Sociological Studies, Sheffield.

Burns, N. \& Grove, S., 2001, The practice of nursing research: Conduct, critique and utilization, W.B. Saunders, Philadelphia.

Byrne, B.M., 2001, Structural equation modelling with AMOS. Basic concepts, applications and programming, LEA, London.

Charlton, K., 1998, 'Health, health care and ageing in Africa: challenges and opportunities', Southern African Journal of Gerontology, Editorial 7(2), 1-3.

DENOSA, 1998, Ethical standards for nurse researchers, DENOSA, Pretoria.

Dhai, A. \& McQuoid-Mason, D., 2011, Bioethics, Human Rights and Health Law: Principles and Practice, Juta \& Company Ltd, Cape Town.

Diener, E., Emmons, R.A., Larsen, R.J. \& Griffin, S., 1985, 'The satisfaction with life scale', Journal of Personality Assessment 49(1), 71-75. http://dx.doi.org/10.1207/ s15327752jpa4901_13, PMid:16367493

Dragaset, J., Nygaard, A., Eide, G.E., Bondevik, M., Nortvedt, M.W., \& Natvig, G.K., 2008 , 'Sense of coherence as a resource in relation to health-related quality of life among mentally intact nursing home residents - a questionnaire study', Health and Quality of Life Outcomes 6(85), 1-9.

Eriksson, M. \& Lindström, B., 2006, 'Antonovsky's sense of coherence scale and the relation with health: a systematic review', Journal of Epidemiology and Community Health 60(5), 376-381. http://dx.doi.org/10.1136/jech.2005.041616, PMid:16614325, PMCid:2563977

Fernández-Ballesteros, R., 2007, GeroPsychology. European perspectives for an ageing world, Hogrefe \& Huber, Gottingen.

Ferreira, M., Møller, V., Prinsloo, F. \& Gillis, L. S., 1992, Multidimensional survey of elderly South Africans, 1990/91: key findings, HSRC/UCT Centre for Gerontology, Cape Town.

Folstein, M.F., Folstein, S.E. \& McHugh, P.R., 1975, "'Mini-mental state”. A practical method for grading the cognitive state of patients for the clinician', Journa of Psychiatric Research 12(3), 189-198. http://dx.doi.org/10.1016/00223956(75)90026-6

Foster, J.J. \& Parker, I., 1995, Carrying out investigations in psychology: Methods and statistics, The British Psychological Society, Leicester.

Geyer, S., 1997, 'Some conceptual considerations on the sense of coherence', Social Science \& Medicine 44(12), 1771-1779. http://dx.doi.org/10.1016/S02779536(96)00286-9

Henje Blom, E.C., Serlachius, E., Larsson, J.O., Theorell, T. \& Ingvar, M., 2010, 'Low Sense of Coherence (SOC) is a mirror of general anxiety and persistent depressive symptoms in adolescent girls - a cross-sectional study of a clinical and a non-clinical cohort', Health Quality Life Outcomes 8, 58. http://dx.doi.org/10.1186/1477-7525-8-58, PMid:20537185, PMCid:2906444 
Howell, D.C., 2004, Fundamental statistics for the behavioural sciences, 5th edn., Brooks/Cole, California.

Kalimo, R., Pahkin, K., Mutanen, P. \& Toppinen-Tanner, S., 2003, 'Staying well or burning out at work: work characteristics and personal resources as long-term predictors', Work Stress 17(2), 109-122. http://dx.doi.org/10.1080/0267837031000149919

Kalimo, R. \& Vuori, J., 1990, 'Work and sense of coherence: resources for competence and life satisfaction', Behavioral Medicine 16(2), 76-89. http://dx.doi.org/10.108 0/08964289.1990.9934595, PMid:2364180

Kinsella, K.G. \& Velkoff, V.A., 2001, An aging world. U.S. Census Bureau, Series P95/011 , U.S. Government Printing Office, Washington, DC.

Kivimäki, M., Feldt, T., Vahtera, J. \& Nurmi, J-E., 2000, 'Sense of coherence and health evidence from two cross-lagged longitudinal samples', Social Science \& Medicine 50(4), 583-597. http://dx.doi.org/10.1016/S0277-9536(99)00326-3

Kleinspehn-Ammerlahn, A., Kotter-Grühn, D., \& Smith, J., 2008, 'Self-perceptions of aging: Do subjective age and satisfaction with aging change during old age?', Journal of Gerontology Series B: Psychological Sciences and Social Sciences 63B(6) 377-385. http://dx.doi.org/10.1093/geronb/63.6.P377

Kline, R.B., 2005, Principles and practices of structural equation modelling, 2 nd edn. The Guilford Press, New York.

Larsson, G. \& Kallenberg, K.O., 1996, 'Sense of coherence, socioeconomic conditions and health: interrelationship in a nation-wide Swedish sample', European Journal of Public Health 6(3), 175-180. http://dx.doi.org/10.1093/eurpub/6.3.175

Leppänen, A-M., 1999, Life in control? Investigation of Aaron Antonovsky's theory of sense of coherence and the feasibility of the concept in empirical data, University of Helsinki, Department of Social Policy, Helsinki. PMCid:2144359

Löckenhoff, C.E., De Fruyt, F., Terracciano, A., McCrae, R.R., De Bolle, M. \& Costa, P.T. Jr., e al., 2009, 'Perceptions of aging across 26 cultures and their culture-level associates', Psychology and Aging 24(4), 941-954. http://dx.doi.org/10.1037/a0016901 PMid:20025408, PMCid:2933107

Lundberg, O., 1996, 'Sense of coherence and population's health', Sosiaalilääketieteellinen Aikakauslehti 33, 265-273.

Lundberg, O., 1997, 'Childhood conditions, sense of coherence, social class and adult ill health: exploring their theoretical and empirical relations', Social Science \& Medicine 44(6), 821-831. http://dx.doi.org/10.1016/S0277-9536(96)00184-0

Lundberg, O. \& Nyström Peck, M. 1994, 'Sense of coherence, social structure and health: evidence from population survey in Sweden', European Journal Public Health 4(4), 252-257. http://dx.doi.org/10.1093/eurpub/4.4.252

Maroco, J., 2010, Análise de equações estruturais: fundamentos teóricos, software e aplicações [Structural equation analysis: Theoretical fundamentals, software and applications], Report Number, Pêro Pinheiro.

Mouton, J., 1996, Understanding social research, Van Schaik, Pretoria.

Nimrod, G. \& Kleiber, D.A., 2007, 'Reconsidering change and continuityinlaterlife: Toward an innovation theory of successful aging', International Journal of Aging and Human Development 65(1), 1-22. http://dx.doi.org/10.2190/Q4G5-7176-51Q2-3754, PMid:17703747

Park, D.C., Gutchess, A.H., Meade, M.L. \& Stine-Morrow, E.A.L., 2007, 'Improving cognitive function in older adults: Nontraditional approaches', Journals of Gerontology: Series B 62B Special Issue 1, 45-52.

Petrie, K. \& Brook, R., 1992. 'Sense of coherence, self-esteem, depression and hopelessness as correlates of reattempting suicide', British Journal of Clinical

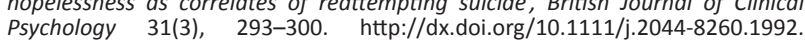
Psychology 31(3), 293-30
tb00996.x, PMid:1393158

Polit, D.F. \& Hungler, B.P., 1995, Nursing research: principles and methods, J.B. Lippincott, Philadelphia.

Polit, F.D. \& Beck, C.T., 2008, Nursing research: Generating and assessing evidence for nursing practice, 8th edn., Lippincott Williams \& Wilkins, Philadelphia.

Ryff, C.D., 1989, 'Beyond Ponce de Leon and life satisfaction: new directions in quest of successful aging', International Journal of Behavioral Development 12(1), 35-55. $\mathrm{http}: / /$ dx.doi.org/10.1177/016502548901200102

Sagy, S. \& Antonovsky, A., 1990, 'Coping with retirement: Does the sense of coherence matter less in the Kibbutz?', International Journal of Health Science 1, 233-242.
Sairenchi, T., Haruyama, Y., Ishikawa, Y., Wada, K., Kimura, K. \& Muto, T., 2011, 'Sense of coherence as a predictor of onset of depression among Japanese workers: A cohort study', BMC Public Health 11, 205. http://dx.doi.org/10.1186/1471-2458cohort study', BMC Public Health 11, 205.

Smith, J., Borchelt, M., Maier, H. \& Jopp, D., 2002, 'Health and well-being in the young old and oldest old', Journal of Social Issues 58(4), 715-732. http://dx.doi. org/10.1111/1540-4560.00286

Söderberg, S., Lundman, B. \& Nordberg, A., 1997, 'Living with fibromyalgia: Sense of coherence, perception of well-being, and stress in daily life', Research in Nursing \& Health 20(6), 495-503. http://dx.doi.org/10.1002/(SICI)1098240X(199712)20:6<495::AID-NUR4>3.0.CO;2-H

Steiner, A., Raube K., Stuck, A.E., Aronow, H.U., Draper, D., Rubenstein, L.Z., et al., 1996, 'Measuring psychosocial aspects of well-being in older community residents: Performance of four short scales', Gerontologist 36(1), 54-62. http:// dx.doi.org/10.1093/geront/36.1.54, PMid:8932410

Suominen S., 1993, Perceived health and life control: A theoretical review and empirical study about the connections between health and life control determined according to the strength of the sense of coherence, STAKES, National Research and Development Centre for Welfare and Health, Research Reports, University of Jyväskylä, Finland. http://dx.doi.org/10.1016/S0022-3999(00)00216-6

Suominen, S., Blomberg, H., Helenius, H. \& Koskenvuo, M., 1999, 'Sense of coherence and health: Does the association depend on resistance resources? A study of 3115 adults in Finland', Psychology and Health 15(5), 1-12.

Suominen, S., Helenius, H., Blomberg, H., Uutela, A. \& Koskenvuo, M., 2001, 'Sense of coherence as predictor of subjective state of health. Results of 4 years of followup of adults', Journal of Psychosomatic Research 50(2), 77-86. http://dx.doi. org/10.1016/S0022-3999(00)00216-6

Surtees, P., Wainwright, N., Luben, R., Khaw, K. \& Day, N., 2003, 'Sense of coherence and mortality in men and women in the EPIC-Norfolk United Kingdom prospective cohort study', American Journal of Epidemiolog
dx.doi.org/10.1093/aje/kwg272, PMid:14652305

Torres, S., 2003, 'A preliminary empirical test of a culturally-relevant theoretical framework for the study of successful aging', Journal of Cross-Cultural Gerontology framework for the study of successful aging', Journal of Cross-Cultural Gerontology

United Nations, Department of Economic and Social Affairs, Population Division, 2009, World population ageing, United Nations, New York.

Vahtera, J. \& Pentti J., 1995, Resources, health and transition of work life, Työterveyslaitos, Helsinki.

Volanen, S.M., Lahelma, E., Silventoinen, K. \& Suominen, S., 2004, 'Factors contributing to sense of coherence among men and women', European Journal of Public Healt 14(3), 322-330. http://dx.doi.org/10.1093/eurpub/14.3.322, PMid:15369042

Volanen, S.M, Suominen, S., Lahelma, E., Koskenvuo, M. \& Silventoinen, K., 2006, 'Sense of coherence and its determinants: A comparative study of the Finnish speaking majority and the Swedish speaking minority in Finland', Scandinavian Journa Public Health 34(5), 515-525. http://dx.doi.org/10.1080/14034940600585812, PMid:16990163

Wahrendorf, M. \& Siegrist, J., 2010, 'Are changes in productive activities of older people associated with changes in their well-being? Results of a longitudinal
European study', European Journal of Ageing 7(2), 59-68. http://dx.doi. European study', European Jo
org/10.1007/s10433-010-0154-4

Ward, R.A., 2010, 'How old am I? Perceived age in middle and later life', The International Journal of Aging and Human Development 71(3), 167-184. http:// Ix.doi.org/10.2190/AG.71.3.a

Weisberg, S., 1985, Applied linear regression, Wiley \& Son, New York. PMCid:1028564

Wilson, R.S., De Leon, C.F.M., Barnes, L.L., Schneider, J.S., Bienias, J.L., Evans, D.A., et al., 2002, 'Participation in cognitively stimulating activities and risk of incident Alzheimer Disease', JAMA 287(6),742-748. http://dx.doi.org/10.1001/ jama.287.6.742, PMid:11851541

Wolff, A.C. \& Ratner, P.A., 1999, 'Stress, social support and sense of coherence', Western Journal of Nursing Research 21(2), 182-197. http://dx.doi. org/10.1177/01939459922043820, PMid:11512176

World Health Organization, 2003, Directory of Research on Ageing in Africa: 19952003, World Health Organization, Geneva, Switzerland. 